\title{
Mineral nutrient contents of some potato accessions of USA and Bangladesh
}

\author{
M. A. Mahamud*, M. A. H. Chowdhury, M. A. Rahim ${ }^{1}$ and K. M. Mohiuddin \\ Department of Agricultural Chemistry, ${ }^{1}$ Department of Horticulture, Bangladesh Agricultural University, Mymensingh- \\ 2202, Bangladesh, *Email: mdasifbau@gmail.com
}

\begin{abstract}
Twenty two potato accessions from USA were evaluated for nutrient contents. Two Bangladeshi varieties were also included for comparison. Nutritional analyses were performed in the Department of Agricultural Chemistry, BAU during November, 2014 to April, 2015. Considering macro nutrient content, the highest values of N, P, K and S were found in the accession AC 10062 whereas $\mathrm{Ca}$ and $\mathrm{Mg}$ contents were found highest in Bangladeshi variety Cardinal and USA accessions AC 10073, respectively. In case of micro nutrient, the maximum amounts of $\mathrm{Cu}, \mathrm{Mn}, \mathrm{B}$ and $\mathrm{Zn}$ were observed in accession AC 10110, AC 10069, AC 10073 and AC 10109, respectively. Significant positive correlations were observed between $\mathrm{N}-\mathrm{P}, \mathrm{N}-\mathrm{K}$ and $\mathrm{K}-\mathrm{Mn}$ contents while $\mathrm{K}-\mathrm{Mg}$, Mn-B and Cu-B contents were negatively correlated. Considering all the parameters studied, the USA accession AC 10062, AC 10069 and AC 10110 were nutritionally superior to Bangladeshi variety Diamant and Cardinal. The accession AC 10062 was found as the best USA accession to produce nutrient rich potato in Bangladesh.
\end{abstract}

Keyword: USA Potato accession, Nutrient content

\section{Introduction}

The word potato may refer to the plant itself as well as the edible tuber. The potato's story begins about 8,000 years ago near Lake Titicaca, which is at $3,800 \mathrm{~m}$ above sea level in the Andes mountain range of South America, on the border between Bolivia and Peru (Ahmad, 1977). Potato is an ideal crop grown very well in multiple cropping system prevalent countries having tropical and subtropical agro climatic conditions. It is used as a staple food in many countries of the world, but mainly as a vegetable in Bangladesh (Hussain, 1995). Potato is the $4^{\text {th }}$ most important crop of Bangladesh. It alone contributes to about $63 \%$ of the total annual vegetables production in Bangladesh (BBS, 2014). Potato varieties grown in Bangladesh mostly are white fleshed. In 2007, a number of colored potato accession has been introduced from University of Wisconsin, Madison, USA and finally in Germplasm Center of Bangladesh Agricultural University. Their yield potential was very high considering climatic condition of Bangladesh. Nutritional status of those varieties is yet to be studied in Bangladesh.

Potato is a frequent item in the human diet; it is used in a variety of ways. It supplies the necessary daily requirements of various substances including macro and micro elements. Humans require at least 25 mineral elements for their well-being (White and Brown, 2010) and these mineral elements enter the food chain through plants. Potatoes are also an excellent source of these elements. Potatoes are an important source of different dietary minerals. Potato is listed as providing $18 \%$ of the RDA of $\mathrm{K}, 6 \%$ of $\mathrm{Fe}, \mathrm{P}$ and $\mathrm{Mg}$, and $2 \% \mathrm{Ca}$ and $\mathrm{Zn}$ (True et al., 1979). There are significant differences in major and trace mineral contents amongst different genotypes of potato (True et al., 1978). Potassium levels varied the most and manganese the least (Andre et al., 2007). So, the present research was carried out to characterize the USA potato accession in relation to nutrient contents and selecting suitable ones for commercial cultivation under Bangladesh condition.

\section{Materials and Methods}

In order to study nutrient contents, twenty two potato accessions of USA and two varieties from Bangladesh were analyzed. The USA accessions were AC 10016, AC 10062, AC 10063, AC 10064, AC 10068, AC 10069, AC 10072, AC 10073, AC 10074, AC 10076, AC 10077, AC 10078, AC 10081, AC 10097, AC 10109, AC 10110, AC 10112, AC 10120, AC 10122, AC 10123, AC 10125 and AC 10190, along with two varieties Diamant and Cardinal from Bangladesh. Potato tuber samples were collected 
from Horticulture Farm, Bangladesh Agricultural University, Mymensingh. For chemical analysis, samples were oven dried at $80^{\circ} \mathrm{C}$ for 72 hours and then ground. Total $\mathrm{N}$ was analyzed using Kjeldahl method. For the determination of other nutrients, the samples were digested by using di-acid mixture $\left(\mathrm{HNO}_{3}: \mathrm{HClO}_{4}=\right.$ 2:1) as described as Singh et al. (1999). Nutrient contents (P, K, Ca, Mg, S, Cu, Mn, Zn and B) of different potato accessions were determined by standard methods of analysis (Page et al., 1982; Ghosh et al., 1983; Tandon, 1995). The data were analyzed using Complete Randomized Design (CRD) and the pair comparisons were performed by DMRT test at $5 \%$ level of probability (Gomez and Gomez, 1984).

\section{Results}

The mineral nutrients are important potato quality criteria because of their physiological and nutritional value in human food (Högy and Frangmeier, 2009). In this study USA potato accessions and Bangladeshi varieties differed significantly with respect to tuber macro and micro nutrient concentrations.

\section{Macro nutrient contents}

\section{Nitrogen}

The experimental result showed that $\mathrm{N}$ content varied significantly among different accessions. The results have been sown in Table 1. The highest amount of $\mathrm{N}$ was found in the accession AC 10062 $(2.19 \%)$ which had statistical similarity with the second highest accession AC $10069(2.13 \%)$ and the third highest in the accession AC 10110 (1.98\%) statistically differed with previous two. The lowest amount of $\mathrm{N}$ content was found in the accession AC $10122(0.89 \%)$ which was identical with the accession AC $10109(1.00 \%)$.

\section{Phosphorus}

The data on the $P$ content of potato tubers were analyzed and shown in Table 1 . The data showed significant variation in $\mathrm{P}$ content. Among the accessions it was observed that $\mathrm{P}$ content varied within the range of $0.12-0.47 \%$. The highest $P$ content was observed in the accession AC 10062 which was statistically identical with the accession AC 10110 (0.43\%), AC 10069 (0.40\%), and AC 10125 (0.39\%). On the other hand the lowest P content was observed in the accession AC 10016 which was statistically identical with the accession AC 10068( 0.18\%), AC 10074 (0.19\%) and 10097 (0.19\%).

\section{Potassium}

Potassium content is one of the important parameter to evaluate the nutritional status of potato tuber. The results of $\mathrm{K}$ content of different potato accessions have been presented in Table 1 . The results showed that $\mathrm{K}$ content varied within the range of $1.45-2.58 \%$. The highest amount of $\mathrm{K}$ was found in the accession AC 10062 followed by the accession AC 10069 (2.35\%) and the accession AC 10110 (2.24\%). The lowest amount of $\mathrm{K}$ was observed in the accession AC 10112, statistically similar with the accession AC $10072(1.52 \%)$ and AC $10123(1.55 \%)$ respectively.

\section{Sulphur}

The S content of potato tubers varied significantly in different accessions or varieties as shown in Table 1. The highest S content was found in the accession AC $10062(0.39 \%)$ which was not significantly higher than the $S$ content of second and third highest accession AC $10069(0.38 \%)$ and Cardinal $(0.36 \%)$, respectively. The lowest S content was in the accession AC 10076 and AC $10123(0.07 \%)$, the second and third lowest S content were obtained from the accession AC $10109(0.08 \%)$ and AC $10190(0.09 \%)$ were statistically identical.

\section{Calcium}

The effect of accession on Ca content in potato tuber was statistically significant (Table 1). The highest Ca content $(0.15 \%)$ was found in Cardinal which was statistically alike with the accession AC 10125 and AC 10069 (0.14\%). The lowest amount of Ca was observed in the accession AC $10016(0.03 \%)$ which was statistically similar to that of the accession AC 10077 (0.04\%). 


\section{Magnesium}

The results presented in Table 1 showed that potato accessions had significant effect on $\mathrm{Mg}$ content. The highest Mg content was observed in the accession AC $10073(0.34 \%)$ identically followed by accession AC 10072 and AC 10112 (0.33\%). The lowest Mg content was observed in the accession AC 10125 $(0.07 \%)$ identically followed by the variety Cardinal $(0.08 \%)$ and the accession AC $10062(0.10 \%)$.

Table 1. Macronutrient contents of some potato accessions of USA and Bangladesh

\begin{tabular}{|c|c|c|c|c|c|c|c|}
\hline \multirow{2}{*}{$\begin{array}{l}\text { SI. } \\
\text { no. }\end{array}$} & \multirow{2}{*}{ Accession } & \multicolumn{6}{|c|}{ Nutrient content (\% dry weight) } \\
\hline & & Nitrogen & Phosphorus & Potassium & Sulphur & Calcium & Magnesium \\
\hline 1 & 10016 & $1.57 \mathrm{fgh}$ & $0.12 \mathrm{k}$ & $1.86 f-i$ & $0.11 \mathrm{ijk}$ & $0.026 \mathrm{k}$ & $0.16 \mathrm{gh}$ \\
\hline 2 & 10062 & $2.19 a$ & $0.47 a$ & $2.58 a$ & $0.39 a$ & $0.086 f g$ & $0.10 \mathrm{~lm}$ \\
\hline 3 & 10063 & $1.73 \mathrm{de}$ & $0.37 \mathrm{~b}-\mathrm{e}$ & $1.85 \mathrm{~g}-\mathrm{j}$ & $0.24 c-f$ & $0.12 b c$ & $0.13 \mathrm{ij}$ \\
\hline 4 & 10064 & $1.82 \mathrm{~cd}$ & $0.32 c-f$ & $1.93 e-h$ & $0.26 \mathrm{cde}$ & $0.13 \mathrm{bc}$ & $0.14 \mathrm{hi}$ \\
\hline 5 & 10068 & $1.04 \mathrm{~m}$ & $0.18 \mathrm{ijk}$ & $1.67 \mathrm{j}-\mathrm{m}$ & $0.16 f-j$ & $0.13 b c$ & $0.16 \mathrm{~g}$ \\
\hline 6 & 10069 & $2.13 a$ & $0.40 \mathrm{abc}$ & $2.35 b$ & $0.38 a$ & $0.14 a b$ & $0.12 \mathrm{jk}$ \\
\hline 7 & 10072 & $1.05 \mathrm{~m}$ & $0.33 c-f$ & $1.52 \mathrm{mn}$ & $0.24 \mathrm{def}$ & $0.13 \mathrm{bc}$ & $0.33 a$ \\
\hline 8 & 10073 & 1.191 & $0.28 \mathrm{fgh}$ & $1.68 \mathrm{i}-\mathrm{m}$ & $0.19 \mathrm{e}-\mathrm{i}$ & $0.06 \mathrm{hi}$ & $0.34 a$ \\
\hline 9 & 10074 & $1.54 \mathrm{gh}$ & $0.19 \mathrm{ijk}$ & $1.75 \mathrm{ijk}$ & $0.21 \mathrm{~d}-\mathrm{g}$ & $0.10 f$ & $0.29 \mathrm{c}$ \\
\hline 10 & 10076 & $1.68 \mathrm{efg}$ & 0.30 efg & 2.03def & $0.07 \mathrm{k}$ & $0.05 i j$ & $0.27 \mathrm{c}$ \\
\hline 11 & 10077 & $1.65 \mathrm{efg}$ & $0.34 c-f$ & $1.72 \mathrm{i}-\mathrm{I}$ & $0.19 \mathrm{e}-\mathrm{i}$ & $0.04 \mathrm{jk}$ & $0.18 \mathrm{f}$ \\
\hline 12 & 10078 & $1.31 \mathrm{jkl}$ & $0.13 \mathrm{jk}$ & $1.69 \mathrm{i}-\mathrm{m}$ & $0.35 a b$ & $0.10 \mathrm{ef}$ & $0.23 d$ \\
\hline 13 & 10081 & $1.38 \mathrm{ij}$ & $0.21 \mathrm{hij}$ & $1.68 \mathrm{i}-\mathrm{m}$ & $0.20 \mathrm{~d}-\mathrm{h}$ & $0.12 b c$ & $0.22 e$ \\
\hline 14 & 10097 & $1.45 \mathrm{hi}$ & $0.19 \mathrm{ijk}$ & $1.71 \mathrm{i}-\mathrm{I}$ & $0.12 \mathrm{~h}-\mathrm{k}$ & $0.08 \mathrm{fg}$ & $0.24 d$ \\
\hline 15 & 10109 & $1.00 \mathrm{mn}$ & $0.32 \mathrm{def}$ & 1.95 efg & $0.08 \mathrm{jk}$ & $0.07 \mathrm{gh}$ & $0.19 f$ \\
\hline 16 & 10110 & $1.98 b$ & $0.43 a b$ & $2.24 b c$ & $0.32 \mathrm{abc}$ & $0.13 \mathrm{bc}$ & $0.16 \mathrm{~g}$ \\
\hline 17 & 10112 & $1.21 \mathrm{kl}$ & 0.30 efg & $1.45 n$ & $0.15 \mathrm{ghk}$ & $0.12 \mathrm{~cd}$ & $0.33 a$ \\
\hline 18 & 10120 & $1.34 \mathrm{ijk}$ & $0.26 f-i$ & $1.60 \mathrm{k}-\mathrm{n}$ & $0.27 \mathrm{bcd}$ & $0.13 b c$ & $0.21 \mathrm{e}$ \\
\hline 19 & 10122 & $0.89 n$ & $0.22 \mathrm{ghi}$ & $1.77 \mathrm{~h}-\mathrm{k}$ & $0.23 \mathrm{~d}-\mathrm{g}$ & $0.11 \mathrm{cde}$ & $0.17 f g$ \\
\hline 20 & 10123 & $1.26 \mathrm{jkl}$ & $0.23 \mathrm{ghi}$ & $1.55 \mathrm{Imn}$ & $0.07 \mathrm{k}$ & $0.10 \mathrm{def}$ & $0.29 \mathrm{c}$ \\
\hline 21 & 10125 & $1.90 \mathrm{bc}$ & $0.39 a-d$ & $2.16 \mathrm{~cd}$ & $0.33 a b c$ & $0.14 a b$ & $0.07 n$ \\
\hline 22 & 10190 & $1.66 \mathrm{efg}$ & $0.26 f-i$ & $1.67 \mathrm{klm}$ & $0.09 \mathrm{jk}$ & $0.12 \mathrm{bc}$ & $0.31 b$ \\
\hline 23 & Cardinal & $1.91 \mathrm{bc}$ & $0.38 \mathrm{~b}-\mathrm{e}$ & $2.08 \mathrm{cde}$ & $0.36 a$ & $0.15 a$ & $0.08 \mathrm{mn}$ \\
\hline 24 & Diamant & $1.70 \mathrm{def}$ & $0.34 c-f$ & 1.98efg & $0.28 \mathrm{bcd}$ & $0.13 \mathrm{bc}$ & $0.11 \mathrm{kl}$ \\
\hline $\mathrm{LSD}_{0.05}$ & & 0.127 & 0.073 & 0.16 & 0.07 & 0.02 & 0.02 \\
\hline CV (\%) & & 5.13 & 13.88 & 5.10 & 3.98 & 9.61 & 4.56 \\
\hline $\mathrm{SE}( \pm)$ & & 0.08 & 0.02 & 0.06 & 0.02 & 0.007 & 0.017 \\
\hline
\end{tabular}




\section{Micro nutrient contents}

\section{Copper}

The results of $\mathrm{Cu}$ content of different potato accessions or varieties have been presented in Table 2. The results showed that $\mathrm{Cu}$ content varied within the range of $10.14-35.77 \mu \mathrm{g} \mathrm{g}^{-1}$. The highest amount of $\mathrm{Cu}$ was found in the accession AC 10110 followed by the accession AC 10069 (35.57 $\left.\mu \mathrm{g} \mathrm{g}^{-1}\right)$ and AC 10062 $\left(34.07 \mathrm{\mu g} \mathrm{g}^{-1}\right)$ were the second and third highest, respectively. The lowest amount of Cu was observed in the accession AC 10076 statistically similar with the accession AC $10097\left(11.08 \mu^{-1} g^{-1}\right)$ and AC 10073 $\left(11.68 \mu^{-1} \mathrm{~g}^{-1}\right.$, respectively.

\section{Manganese}

The Mn content of potato tubers varied significantly in different accessions as shown in Table 2. The highest $\mathrm{Mn}$ content was found in the accession AC $10069\left(50.61 \mathrm{\mu g} \mathrm{g}^{-1}\right)$ which was not significantly higher than the second and third highest the accession AC $10062\left(49.19 \mu^{-1}\right)$ and AC $10110\left(48.27 \mu \mathrm{g} \mathrm{g}^{-1}\right)$, respectively. The lowest $\mathrm{Mn}$ content was in the accession $\mathrm{AC} 10097\left(7.43 \mathrm{\mu g} \mathrm{g}^{-1}\right)$, which was statistically identical with the second lowest accession AC $10109\left(9.35 \mu \mathrm{g} \mathrm{g}^{-1}\right)$ and AC $10073\left(11.60 \mu \mathrm{g} \mathrm{g}^{-1}\right)$ was statistically differed with previous two.

\section{Boron}

The effect of accession or varieties on the B content in potato tuber was statistically significant (Table 2). The highest $B$ content $\left(15.78 \mu \mathrm{g} \mathrm{g}^{-1}\right)$ was found in the accession AC 10073 which was statistically alike with the accession AC 10190, AC 10078, AC 10072 and AC 10120. The lowest amount of $B$ content was observed in the accession AC $10062\left(3.67 \mathrm{\mu g} \mathrm{g}^{-1}\right)$ which was statistically similar to that of accession AC 10069, AC 10110, variety Cardinal and AC 10125.

\section{Zinc}

The results have been presented in Table 2 showed that accessions had significant effect on $\mathrm{Zn}$ content. The range of $\mathrm{Zn}$ content varied between 21.80 to $45.80 \mathrm{\mu g} \mathrm{g}^{-1}$. The highest amount of $\mathrm{Zn}$ content was observed in Cardinal closely followed by accession AC $10125\left(44.63 \mathrm{\mu g} \mathrm{g}^{-1}\right)$ and variety Diamant $(44.57$ $\left.\mu \mathrm{g} \mathrm{g}^{-1}\right)$. The lowest Zn content was observed in the accession AC $10109\left(21.80 \mu \mathrm{g} \mathrm{g}^{-1}\right)$ closely followed by the accession AC $10120\left(23.33 \mu \mathrm{g} \mathrm{g}^{-1}\right)$ and $10072\left(23.77 \mu \mathrm{g} \mathrm{g}{ }^{-1}\right)$. 
Table 2. Micronutrient contents of some potato accessions of USA and Bangladesh

\begin{tabular}{|c|c|c|c|c|c|}
\hline \multirow{2}{*}{ SI. no. } & \multirow{2}{*}{ Accession } & \multicolumn{4}{|c|}{ Nutrient Content ( $\mu \mathrm{g} \mathrm{g}^{-1}$ dry weight) } \\
\hline & & Copper & Manganese & Boron & Zinc \\
\hline 1 & 10016 & $24.27 \mathrm{~cd}$ & $38.31 \mathrm{~cd}$ & $10.52 \mathrm{bc}$ & $25.13 \mathrm{~h}-\mathrm{k}$ \\
\hline 2 & 10062 & $34.07 a$ & $49.19 a$ & $3.670 \mathrm{i}$ & $36.07 \mathrm{bc}$ \\
\hline 3 & 10063 & $23.47 \mathrm{~cd}$ & $28.94 \mathrm{~h}$ & 7.147 efg & $32.97 \mathrm{de}$ \\
\hline 4 & 10064 & $25.10 \mathrm{c}$ & $35.15 \mathrm{ef}$ & $7.233 \mathrm{efg}$ & $38.33 b$ \\
\hline 5 & 10068 & $13.48 \mathrm{~g}$ & $14.131 \mathrm{~m}$ & $10.93 b c$ & $32.43 \mathrm{cde}$ \\
\hline 6 & 10069 & $35.57 a$ & $50.61 a$ & $4.71 \mathrm{hi}$ & $44.27 a$ \\
\hline 7 & 10072 & $15.98 f$ & $15.47 \mathrm{kl}$ & $14.68 \mathrm{a}$ & 23.77ijk \\
\hline 8 & 10073 & $11.68 \mathrm{gh}$ & $11.60 \mathrm{mn}$ & $15.78 a$ & $42.43 a$ \\
\hline 9 & 10074 & $21.99 \mathrm{de}$ & $32.08 \mathrm{~g}$ & $9.83 c d$ & 26.10hij \\
\hline 10 & 10076 & $10.14 \mathrm{~h}$ & $32.42 \mathrm{fg}$ & $8.00 \mathrm{ef}$ & 30.57 efg \\
\hline 11 & 10077 & $30.47 \mathrm{~b}$ & $43.01 \mathrm{~b}$ & $8.37 \mathrm{de}$ & $35.90 \mathrm{bc}$ \\
\hline 12 & 10078 & 17.46 & $18.12 \mathrm{k}$ & $14.96 a$ & $31.57 \mathrm{def}$ \\
\hline 13 & 10081 & $16.71 \mathrm{f}$ & $17.80 \mathrm{k}$ & $11.43 b c$ & $25.37 \mathrm{~h}-\mathrm{k}$ \\
\hline 14 & 10097 & $11.08 \mathrm{gh}$ & 7.430 & $10.93 b c$ & $25.23 \mathrm{~h}-\mathrm{k}$ \\
\hline 15 & 10109 & $22.36 \mathrm{de}$ & $9.35 \mathrm{no}$ & 7.14efg & $21.80 \mathrm{k}$ \\
\hline 16 & 10110 & $35.77 a$ & $48.27 a$ & $4.85 \mathrm{hi}$ & $38.57 \mathrm{~b}$ \\
\hline 17 & 10112 & $17.77 f$ & $21.86 j$ & $10.06 \mathrm{~cd}$ & $35.33 \mathrm{bcd}$ \\
\hline 18 & 10120 & $18.09 f$ & $24.19 i j$ & $14.50 a$ & $23.33 \mathrm{jk}$ \\
\hline 19 & 10122 & $20.89 e$ & $35.94 \mathrm{de}$ & $12.07 \mathrm{~b}$ & $28.17 \mathrm{fgh}$ \\
\hline 20 & 10123 & $18.49 f$ & 26.91hi & $11.73 b c$ & 27.63ghi \\
\hline 21 & 10125 & $33.50 \mathrm{a}$ & $44.83 b$ & $5.403 \mathrm{ghi}$ & $44.63 a$ \\
\hline 22 & 10190 & $13.18 \mathrm{~g}$ & $12.35 \mathrm{~m}$ & $15.59 a$ & $34.70 \mathrm{bcd}$ \\
\hline 23 & Cardinal & $28.60 \mathrm{~b}$ & $39.56 c$ & 5.193hi & $45.80 a$ \\
\hline 24 & Diamant & $30.80 \mathrm{~b}$ & $44.87 \mathrm{~b}$ & $6.30 \mathrm{fgh}$ & $44.57 a$ \\
\hline $\mathrm{LSD}_{0.05}$ & & 2.31 & 2.76 & 1.68 & 3.60 \\
\hline CV (\%) & & 6.38 & 5.76 & 10.69 & 6.64 \\
\hline $\mathrm{SE}( \pm)$ & & 1.63 & 2.83 & 0.76 & 1.55 \\
\hline
\end{tabular}

\section{Correlation among different parameters}

Different correlation among $\mathrm{N}, \mathrm{P}, \mathrm{K}$ and $\mathrm{Mn}(\mathrm{N}-\mathrm{P}, \mathrm{N}-\mathrm{K}$ and $\mathrm{K}-\mathrm{Mn})$ contents in potato tuber indicate significant positive correlation at $1 \%$ level of probability with each other (Fig.2). The value of correlation of coefficient $(r)$ was $0.61^{* *}, 0.78^{* *}$ and $0.71^{* *}$, respectively with the regression line $y=0.160 x+0.046 ; y=$ $0.597 x+0.942$ and $y=35.79 x-37.06$. On the other hand significant negative relationship was observed among K-Mg, Mn-B and Cu-B contents at $1 \%$ level of probability with each other (Fig.2). The value of correlation of coefficient $(r)$ was $-0.72^{* *},-0.76^{* *}$ and $-0.78^{* *}$, respectively with the regression line $y=-$ $0.219 x+0.607 ; y=-0.199 x+15.46$ and $y=-0.364 x+17.67$ 

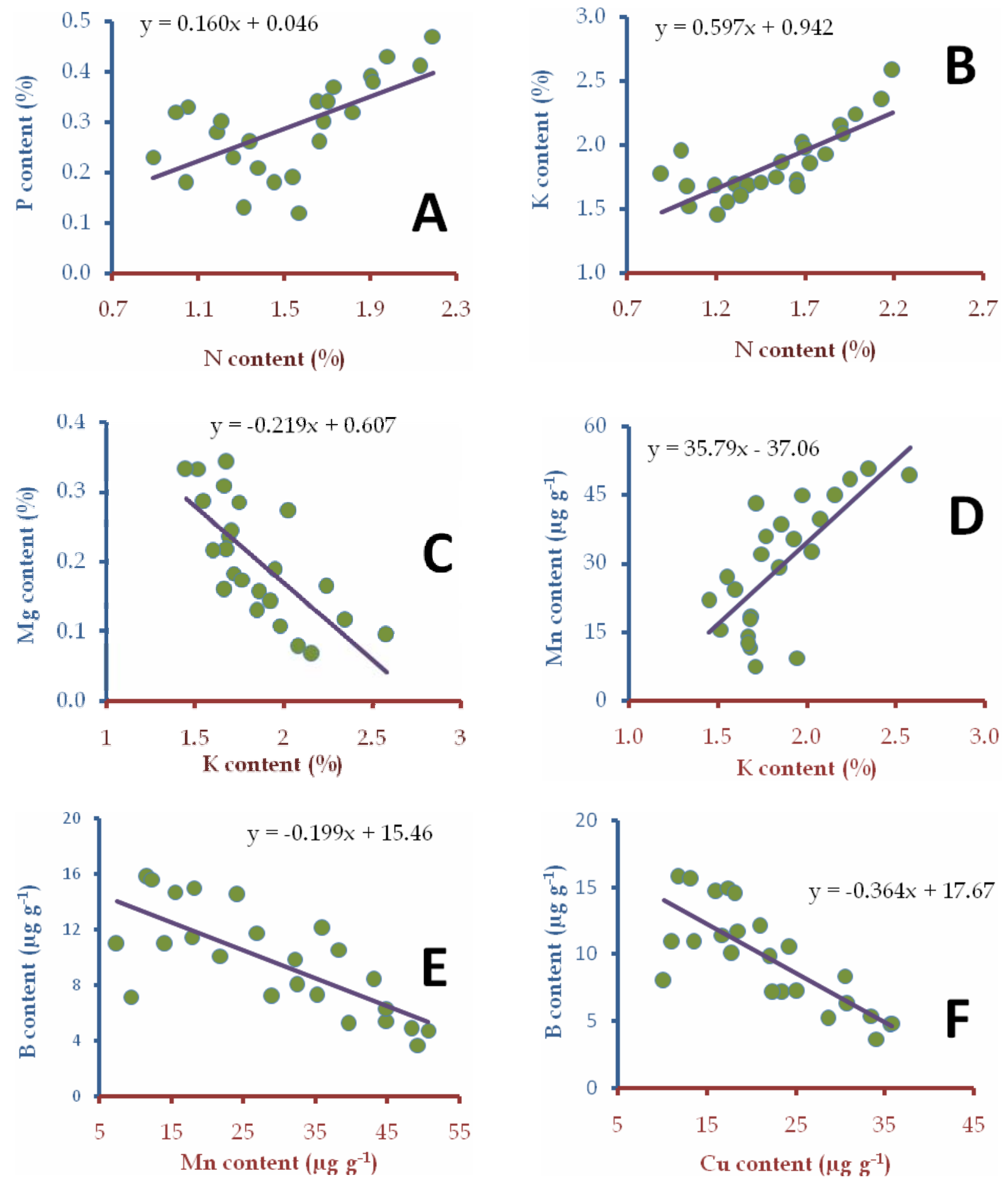

Fig. 2. Correlation between $N$ and $P$ content $(A), N$ and $K$ content $(B), K$ and $M g$ content (C), $K$ and $M n$ content (D), $\mathrm{Mn}$ and $\mathrm{B}$ content $(\mathrm{E}), \mathrm{Cu}$ and $\mathrm{B}$ content $(\mathrm{F})$ of different potato accessions of USA and Bangladesh 


\section{Discussion}

A wide range of mineral elements occurs in fruits and vegetables, which are primary dietary source. The importance of optimal mineral intake to maintain good health is widely recognized (Avioli, 1988). Potatoes are an important source of different dietary minerals. Potato is listed as providing $18 \%$ of the Reference Daily Intake (RDA) of potassium, phosphorus and magnesium, and $2 \%$ calcium and zinc (True et al., 1979). Potatoes rank highest for $\mathrm{K}$ content among 20 most frequently consumed cereals including rice and wheat, raw vegetables and fruits. (Casanas et al., 2002; Rivero et al., 2003: Sanchez-Castillo. 1998). The $\mathrm{K}$ content in potato is as even higher amount than in banana, a food often recommended by dieticians to people who need to supplement potassium consumption (Lisinka and Leszczynski, 1989).

In this study the P, K, Ca and Mg content are in agreement with the study of Ekin (2011). In general, the contents of $\mathrm{N}, \mathrm{P}, \mathrm{K}, \mathrm{S}, \mathrm{Ca}$ and $\mathrm{Mg}$ are similar to those, reported by other authors working on potatoes (Rivero et al., 2003; Tekaling and Hammes, 2005; Andre et al., 2007; DiGiacamo et al., 2007). The present study also showed that the N, P, K and S content of accession AC 10062, AC10069 and AC10110 were higher than the Bangladeshi variety Diamant and Cardinal, which are also high yielding (Kabir 2014).The levels of $\mathrm{Cu}, \mathrm{Mn}$, and $\mathrm{Zn}$ in this study are alike with those reported by Haynes et al. (2012). They observed average $\mathrm{Mn}, \mathrm{Cu}$, and $\mathrm{Zn}$ contents were $10.2,9.9$, and $20.0 \mathrm{mg} \mathrm{kg}{ }^{-1}$ of $\mathrm{FW}$, respectively and concluded that genetic variation had significant influence on micronutrient contents of potato. In general, the contents in $\mathrm{Cu}, \mathrm{Mn}, \mathrm{B}$ and $\mathrm{Zn}$ are also similar to those reported by others (Andre et al., 2007; Rivero et al., 2003, Dugo et al., 2004). B content of most of the tested USA accession are very high than Bangladeshi varieties Diamant and Cardinal.

The differences in macro and micro nutrient concentrations of potato tuber could be explained by several factors. First and foremost is the potato cultivar characteristic. Indeed, the tuber mineral concentrations may vary among genotypes of cultivated potatoes. There is evidence that potato genotypes, grown under identical conditions, have been shown to differ in tuber macro and micro nutrient concentrations (Tekalign and Hammes, 2005; White et al., 2009) and systematic differences in tuber $\mathrm{K}, \mathrm{Mg}, \mathrm{Fe}, \mathrm{Zn}, \mathrm{Mn}$ and $\mathrm{Cu}$ concentrations have been observed between commercial potato cultivars (Rivero et al., 2003; DiGiacomo et al., 2007).

\section{Conclusion}

Nutrient contents of different potato accessions of USA and Bangladesh differed significantly. Among the twenty four accessions under trial the accession AC 10062 was superior to other accessions acknowledging nutrient content. Therefore, accession AC 10062 can be suggested to cultivate in Bangladesh to produce nutritionally superior potato.

\section{Acknowledgement}

We humbly desire to express our profound thanks and gratefulness to the Department of Agricultural Chemistry and Horticulture, BAU for technical support and providing the potato germplasm. We are grateful to the Ministry of Science and Technology, Government of the People's Republic of Bangladesh for providing financial support.

\section{References}

Ahmad, K.U. 1977. Potatoes for the Tropics. p. 71-72, 122. Published by Mrs. Mumtaj Kamal, Bunglow No. 2, West of Agricultural Laboratory, Farmgate, Dhaka-1215.

Andre, C.M., Ghislain, M., Bertin, P., Qufir, M., Herrera, M.D.R., Hoffmann, L., Hausman, J.F.O., Larondelle, Y. and Evers, D. 2007. Andean potato cultivars (Solanum tuberosum L.) as a source of antioxidant and mineral micronutrients. J. Agri. Food Chem., 55: 366-378. 
Avioli, L.V. 1988. Calcium and phosphorus. In: M. E. Shils, E. Young (Edetors). Modern nutrition in health and disease. Lea \& Febiger, Philadelphia, USA.

BBS. 2009. Statistical Year Book of Bangladesh. p.141. Statistics Division, Ministry of Planning, Govt. of the People's Republic of Bangladesh, Dhaka.

Casanas, R.; Gonzalez, M.; Rodriguez, E.; Morrero, A. and Diaz C 2002. Chemometric studies of chemical compounds in five cultivars of potatoes from Tenerife. J. Agri. Food Chem., 50: 2076-2082.

DiGiacomo, F., Signore, D. A. and Giaccio, M. 2007. Determining the geographic origin of potatoes using mineral and trace element content. J. Agri. Food Chem., 55: 860-866.

Dugo, G., Pera, L.L., Turco, L.V., Giuffrida, D. and Restuccia, S. 2004. Determination of copper, zinc, alumminium, lead and cadmium in potatoes (Solanum tubersom L.) using potentiometric stripping method. Food Addit. Contam., 2(7): 649-657.

Ekin, Z. 2011. Some analytical quality characteristics for evaluating the utilization and consumption of potato (Solanum tuberosum L.) tubers. Afr. J. Biotechnol., 10(32): 6001-6010.

Ghosh, A.B., Bajaj, J.C., Hasan, R. and Singh, D. 1983. Soil and Water Testing Method, A Laboratory Manual. Division of Soil Science and Agricultural Chemistry, IARI, New Delhi, India. p. 221-226.

Gomez, A.K. and Gomez, A.A. 1984. Statistical Procedures for Agricultural Research. IRRI, Los Banos, Philippines. p. $207-215$.

Haynes, K.G., Yencho, G.C., Clough, M.E., Henninger, M.R. and Sterrett, S.B. 2012. Genetic Variation for Potato Tuber Micronutrient Content and Implications for Biofortification of Potatoes to Reduce Micronutrient Malnutrition. Am. J. Potato Res., 89: 92-198.

Högy, P. and Fangmeier, A. 2009. Atmospheric $\mathrm{CO}_{2}$ enrichment affects potatoes and tuber quality traits. Eur.J. Agron., 30: 85-94.

Hossain MM, Akhter MI, Sattar MA, Rashid MH, Ali MS 2003: Maintenance of promising variety/ genotypes. Annual Research Reports on tubers crop Improvement, TCRC, BARI, Joydebpur, Gazipur. pp.13-15.

Hussain, M.M. 1995. Seed Production and Storage Technology (in Bengali). p. 255. Mrs. Imtiaz Hussain, Dhaka.

Kabir, H. 2014. Effect of seed tuber size on the growth and yield of twenty three accessions of potato, MS thesis, Department of Horticulture, Bangladesh Agricultural University, Mymensingh.

Lisinska, G. and Leszczynski, W. 1989. Potato science and technology pp. 11-202. Elsevier Science Publishers Ltd., America, New York.

Page, A.L., Miller, R.H. and Keeney, D.R. 1982. Methods of Soil Analysis, Part-2. 2nd Ed. p.98-765. American. Soc. Agron. Inc. Madison, Washington, USA.

Rivero, R.C., Hernandez, P.S., Rodriguez, E.M.R. and Martin, J.D., Romero, C.D. 2003. Mineral concentrations in cultivars of potatoes. Food Chem., 83: 247-253.

Robert, L., Narcy, A., Rock, E., Demigne, C., Mazur, A. and Rémésy, C. 2006. Entire potato consumption improves lipid metabolism and antioxidant status in cholesterol-fed rat. Eur. J. Nutr., 45: 267-274.

Sanchez-Castillo, C. P., Dewey, P.J.S; Aguirre, A.; Lara J.J.; Vaca, R.; de la Barra, P.L., Ortiz, M.; Escamilla, L. and James, W.P.T. 1998. The minerals of Mexican fruits and vegetables. J. Food Com. Anal. 11: 340-356.

Singh, D., Chhonkar, P.K. and Pandey, R.N. 1999. Soil Plant Water Analysis: A Method Manual. IARI, New Delhi, India. p. $72-86$.

Tandon H.L.S. 1995. Methods of Analysis of Soils, Plants, Water and Fertilizers. $2^{\text {nd }}$ Edn. p. 44-45. Fertilizer Development and Consultation Organization, New Delhi.

Tekalign, T. and Hammes, P.S. 2005. Growth and productivity of potato as influenced by cultivar and reproductive growth. II. Growth analysis, tuber yield and quality. Sci. Hort., 105: 29-44.

True, R.H., Ho gan J.M., Augustin, J., Johnson, S.J., Teitzel, C., Toma, R.B. and Orr, P. 1979. Mineral composition of freshly harvested potatoes. American J. Potato Res., 56(7): 339-350.

True, R. H., Hogan, J. M., Augustin, J., Johnson, S. J, Teitzcl, C., Toma, R. B. and Shaw, R. L. 1978. Mineral composition of freshly harvested potatoes. American J. Potato Res., 55(9): 511-519.

Westennann, D.T. 2005. Nutritional Requirements of Potatoes. American J. Potato Res., 82: 301-307.

White, P.J., Bradshaw, J.E., Dale, M.F.B. and Ramsay, G. 2009. Relationships between yield and mineral concentrations in potato tubers. Hort. science, 44(1): 6-11.

White, P.J. and Brown, P.H. 2010. Plant nutrition for sustainable development and global health. Ann. Bot., 105: 1073-1080. 